Egyptian

Orthodontic Journal

\title{
THE EFFECT OF PLATELET RICH PLASMA INJECTION ON RELAPSE OF ORTHODONTICALLY MOVED TEETH IN RABBITS
}

\author{
Abdel-Haffiez S.H ${ }^{1}$, Ismail H.A ${ }^{2}$, Elharouni N.M ${ }^{3}$, Ali H.M ${ }^{4}$ \\ ABSTRACT: \\ Objective: To test the hypothesis that platelet rich plasma \\ (PRP) injection can minimize relapse of orthodontically moved \\ teeth. Material and Methods: Thirty rabbits were randomly and \\ equally divided into three groups $(\mathcal{A}, \mathcal{B}$ and $C$ ). The mock group $C$ \\ $(n=10)$ was further equally divided into $C 1$ and $C 2$ subgroups. \\ A mesializing force was applied to the first molar on both sides in \\ all groups. After achieving orthodontic movement, in groups $\mathcal{A}$ \\ and $\mathcal{B},(P R \mathcal{R})$ was injected on the experimental side while normal \\ saline was injected on the control side. Animals in group $C$ did not \\ receive any injections. Animals in groups $\mathcal{A}$ and $C 1$ were sacrificed \\ after 1 week and animals in groups $\mathcal{B}$ and $C 2$ were sacrificed after \\ four weeks. Amount of first molar relapse in all groups was \\ measured and compared. Results: After 1 week and 4 weeks \\ relapse periods; the distance of relapse in the experimental group \\ was reduced significantly $(\mathcal{P}<0.001)$ when compared with the \\ control and mock groups. No statistically significant difference \\ was found between the relapse observed in the experimental \\ groups in 1 week, and 4 weeks relapse periods; (29.09\%) and \\ (39.16\%) respectively. However, relapse increased significantly \\ $(\mathcal{P}<0.001)$ in both the control and mock groups from 1 week
}

1 - Lecturer of Orthodontics, Faculty of Dentistry, Alexandria University.

2 - Professor of Orthodontics, Faculty of Dentistry, Alexandria University.

3 - Professor of Orthodontics, Faculty of Dentistry, Alexandria University.

4 - Professor of Oral Biology, Faculty of Dentistry, Alexandria University. 
Egyptian

Orthodontic Journal

to 4 weeks relapse period intervals. Conclusion: The injection of platelet rich plasma can significantly reduce the amount of orthodontic relapse following removal of the orthodontic force.

\section{INTRODUCTION}

A strong relationship between the stability of tooth position after orthodontic treatment and the level of patient satisfaction was found ${ }^{(1)}$.

The most common measure to overcome relapse is mechanical retention using a retainer. Several authors ${ }^{(2,3)}$ prescribe permanent mechanical retention as the only way to ensure long-term posttreatment stability, representing an extra burden on patients ${ }^{(4-7)}$. Therefore, finding a logical and safe solution for the unavoidable relapse represents a necessity.

\section{Biological control of tooth movement}

It is well documented that osteoclasts (resorption) and osteoblasts (opposition) are responsible for the alveolar bone remodelling process around the teeth roots resulting in orthodontic tooth movement ${ }^{(8)}$. Relapse following orthodontic treatment is due to tooth movement; however, in an undesired direction. Therefore, control of alveolar bone remodeling around teeth roots by influencing osteoblasts and/or ostoclasts activity can prevent tooth relapse.

The orthodontic literature shows successful biological control of orthodontic relapse by pharmacological agents either by inhibition of osteoclastic activity ${ }^{(9-11)}$ or by promoting osteoblasts function ${ }^{(12-14)}$.

Platelet rich plasma (PRP) is a biologically safe osteoinductive material to regenerate bone

In the past years, the use of autologous platelet rich plasma (PRP) has gained great popularity in a variety of medical fields. Platelet-rich plasma (PRP) use has been approved in the US and European Community for promotion of tissue regeneration in bone, cartilage, ligaments, and tendons in vivo and in humans ${ }^{(15-21)}$. 
Platelet-rich plasma (PRP) is a concentrate of platelets derived from autologous blood with a platelet count up to 5 times the physiologic platelet count in the patient's blood. Human platelets store growth factors that are released from platelets upon their activation. The growth factors produced by human platelets include platelet-derived growth factor (PDGF), insulin-like growth factor (IGF-1), transforming growth factor $\beta$ (TGF- $\beta$ ), basic fibroblast growth factor (FGF), epidermal growth factor (EGF), and vascular endothelial growth factor (VEGF) ${ }^{(22,23)}$.

Therefore, PRP is considered to be a concentrated source of growth factors integral to bone healing ${ }^{(24-26)}$. Platelet-derived growth factor (PDGF) increases collagen deposition, initiates differentiation of progenitor cells towards osteoblastic lineages, and stimulates osteopontin expression (27-29) and this has been shown to play an important role in the healing of bone and the periodontium ${ }^{(30)}$. Localized angiogenic factor delivery (VEGF) has proven beneficial for bone regeneration in numerous animal models by promoting neovascularization, bone turnover, osteoblast migration and mineralization ${ }^{(31,32)}$. Transforming growth factor $\beta$ (TGF- $\beta$ ) acts as osteoinductive by inducing differentiation of osteoblasts from mesenchymal cells ${ }^{(33)}$.

Platelete rich plasma stimulates osteoblast activity ${ }^{(34)}$, accelerate new bone formation and increase new bone volume in the early phase of bone regeneration $^{(35-37)}$. The use of PRP increases the vascularity with an increase of osteoblast and immature osteoid tissue formation; improving the quality and quantity of newly formed bone tissue ${ }^{(38,39)}$. If combined with a bone graft, PRP "Jump-starts" osteogenesis by releasing growth factors at the local site ${ }^{(40)}$; accelerating the rate and degree of bone formation in the bone graft $^{(41)}$.

The use of (PRP) as a biological retainer has not been studied in the literature. A hypothesis that; local injection of platelet rich plasma (PRP) into periodontal tissues following orthodontic tooth movement can minimize orthodontic tooth relapse by promoting osteogenesis and inhibiting osteoclastogenesis needs to be tested. 
The aim of this study was to investigate the effect of periodontal injection of platelet rich plasma (PRP) following orthodontic tooth movement on the amount of relapse of orthodontically moved teeth in a rabbit model.

\section{MATERIAL AND METHODS}

\section{Study animals}

Thirty white male New Zealand rabbits were used.

\section{Study design}

Animals were randomly and equally allocated into one of three groups $\mathrm{A}, \mathrm{B}$ and $\mathrm{C}$ according to a previously generated table using a software program*. In groups A and B; a split-mouth design was used and right and left sides were randomly assigned as experimental and control sides. The experimental side received (PRP) injection, whereas, the control side received saline injection. Group C (mock group); were used to study the physiologic tooth movement following orthodontic tooth movement without any further interventions.

In group A $(n=10)$ : Animals were sacrificed after one week of removing orthodontic force. On the other hand, animals were sacrificed after four weeks of removing orthodontic force in group $B(n=10)$. Group $\mathrm{C}(\mathrm{n}=10)$ was further subdivided into 2 subgroups; group $\mathrm{C} 1(\mathrm{n}=5)$ and group C2 $(n=5)$ where animals were sacrificed after one week and after 4 weeks respectively of removing the orthodontic force.

\section{Procedures}

Rabbits were anesthetized for the procedures by intramuscular injection of Ketamine at a dose of $35 \mathrm{mg} / \mathrm{kg}$ and Xylazine at a dose of $5 \mathrm{mg} / \mathrm{kg}^{(42)}$.

An impression** was taken for the mandibles of all the animals as an initial record of the interdental space between the first and the second molar teeth $(\mathrm{T} 1)^{(12)}$ (Fig. 1).

\footnotetext{
* Urbaniak, G. C., \& Plous, S; Research Randomizer (Version 5.0)

**Speedex light body, Coltene Valedent, Switzerland.
} 


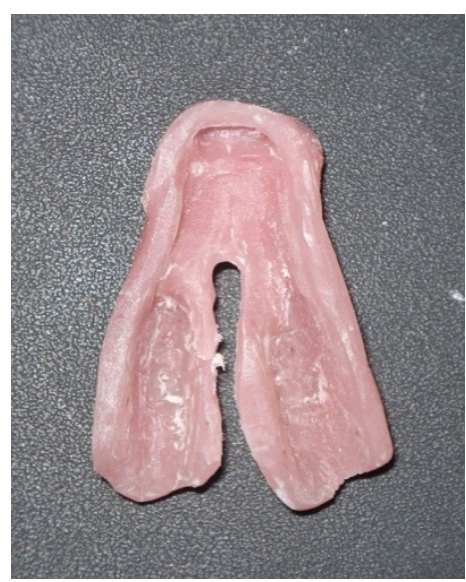

(A)

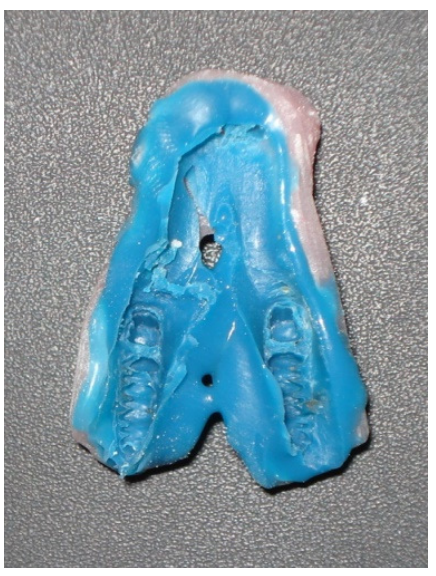

(B)

Fig. 1. (A) Special tray prepared for impression making, (B) Impression tray with light body rubber base after impression making.

A NiTi closed coil spring was fixed between each lower first molar and the incisors using 0.010 " ligature wire passing interdentally between $1^{\text {st }}$ and $2^{\text {nd }}$ molar and wrapped around the $1^{\text {st }}$ molar, and delivering 100 grams of force ${ }^{(43-46)}$ (Fig. 2).
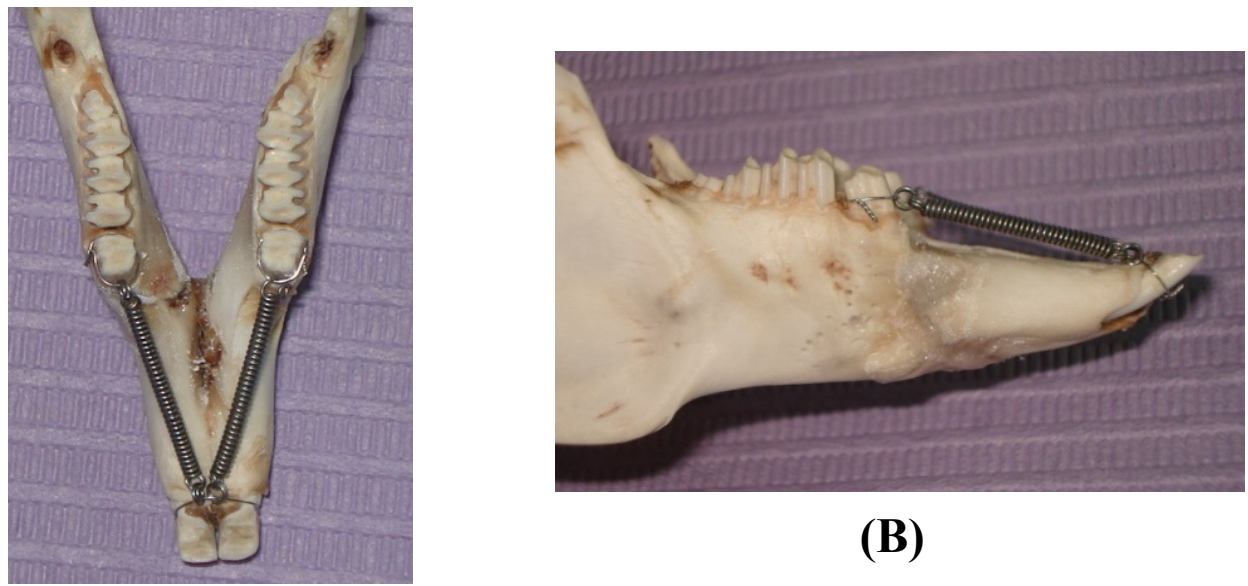

(B)

(A)

Fig. 2. A dried rabbit's mandible showing the appliance design. (A) occlusal view and (B) lateral view 
In order to avoid dislodgement of the appliance and lessen soft tissue irritation of any wire projections; enamel was etched with $37 \%$ phosphoric acid for 30 seconds around the coronal portions of the molars and the incisors, and a thin coat of flowable composite* was applied to the etched surfaces and the overlying ligature wire and cured ${ }^{(44,45)}$. A piece of ligature wire was used to ligate the second molar to the third molar to prevent any possible movement of the second molar with the mesial movement of the first molar by the effect of the gingival interseptal fibers.

\section{Preparation of (PRP):}

Preparation of the (PRP) was done at the laboratories of the Department of Clinical Pathology, Faculty of Medicine, Alexandria University, after 21 days of active orthodontic tooth movement using the 2 step preparation method ${ }^{(47,48)}$.

After 21 days of active tooth movement;

- Animals were anesthetized again

- Springs were removed

- An impression was taken to the mandibles of all the animals to measure the distance between first and second molars on both sides using a digital caliper with accuracy of $0.01 \mathrm{~mm}$ (T2). Three successive measurements were made, and their mean values were used to determine the amount of first molar mesialization.

- Injection of the prepared (PRP) was done around the first molars (experimental side) of all the animals in groups (A \& B), whereas, normal saline was injected around the teeth assigned as controls.

- All the first molars were left without retainers to allow relapse of the mesialized molars to occur by returning toward their original distal positions.

* Z350 XT flow, 3M ESPE, Calif, USA. 
Egyptian

Orthodontic Journal

\section{Animal Euthanasia}

Animal euthanasia was executed following the American Veterinary Medical Association guidelines. Decapitation was performed after administration of $100 \mathrm{mg} / \mathrm{kg}$ intraperitoneal sodium pentobarbital.

Following animal Euthanasia:

- An impression was taken to the mandibles of all the animals, and the distance between first and second molars was measured on both sides using a digital caliper with accuracy of $0.01 \mathrm{~mm}$ (T3). Three successive measurements were made, and their mean values were used.

The amount of first molar movement, first molar relapse, and relapse percentage were calculated according to the following formulas:

- Amount of first molar movement $=\mathrm{T} 2-\mathrm{T} 1$

- Amount of first molar relapse = amount of first molar movement $-\mathrm{T} 3$

- Relapse percentage $=($ amount of relapse $x 100) /$ amount of first molar movement

\section{STATISTICAL ANALYSIS}

All data were expressed as means \pm standard deviations. Statistical significance for platelet count was calculated using paired- $t$ test. Statistical significance for mean amount of first molar relapse between similar groups at different relapse times was calculated using two-sample t-test. Statistical significance for mean amount of first molar relapse among different groups at each relapse period was calculated by analysis of variance (ANOVA) followed by a post hoc Tukey's test when the ANOVA suggested a significant difference. Differences with a $P$ value less than 0.05 were considered significant. 


\section{RESULTS}

After 3 weeks of force application, tooth movement of the first molars ranged from $3 \mathrm{~mm}$ to $3.8 \mathrm{~mm}$, with a mean movement of $3.3 \pm$ $0.23 \mathrm{~mm}$. There were no significant differences in the amount of first molar movement (T2 - T1) between the different groups.

After 1 week of relapse, the distance and percentage of relapse in the experimental group $(0.96 \pm 0.27 \mathrm{~mm} ; 28.79 \% \pm 7.07 \%)$ was significantly less $(\mathrm{P}<0.001)$ than the control group $(1.57 \pm 0.3 \mathrm{~mm}$; $47.7 \% \pm 6.5 \%)$ and the mock group $(1.59 \pm 0.13 \mathrm{~mm} ; 48.7 \% \pm 2.3 \%)$. No significant difference was observed between the control and the mock groups (Fig. 3 and Fig. 4).

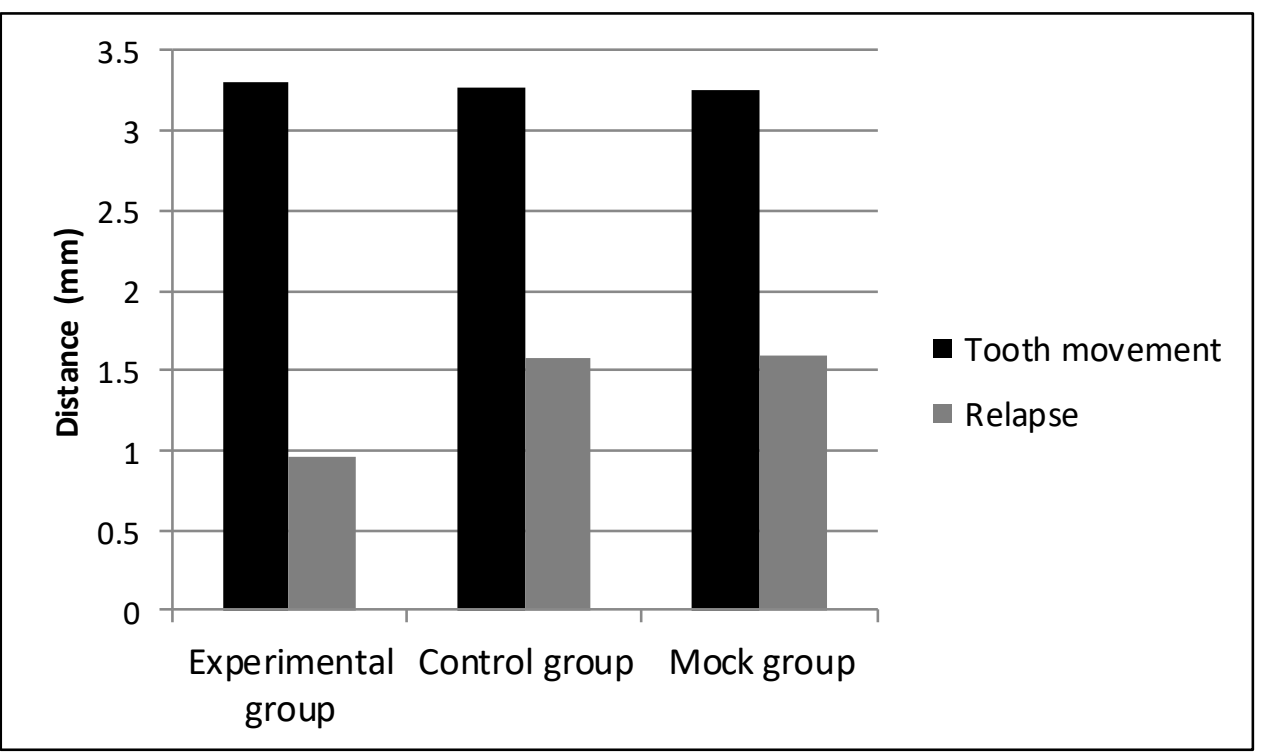

Fig. 3. A bar graph showing initial tooth movement and amount of relapse in the three study groups after 1 week relapse period. 


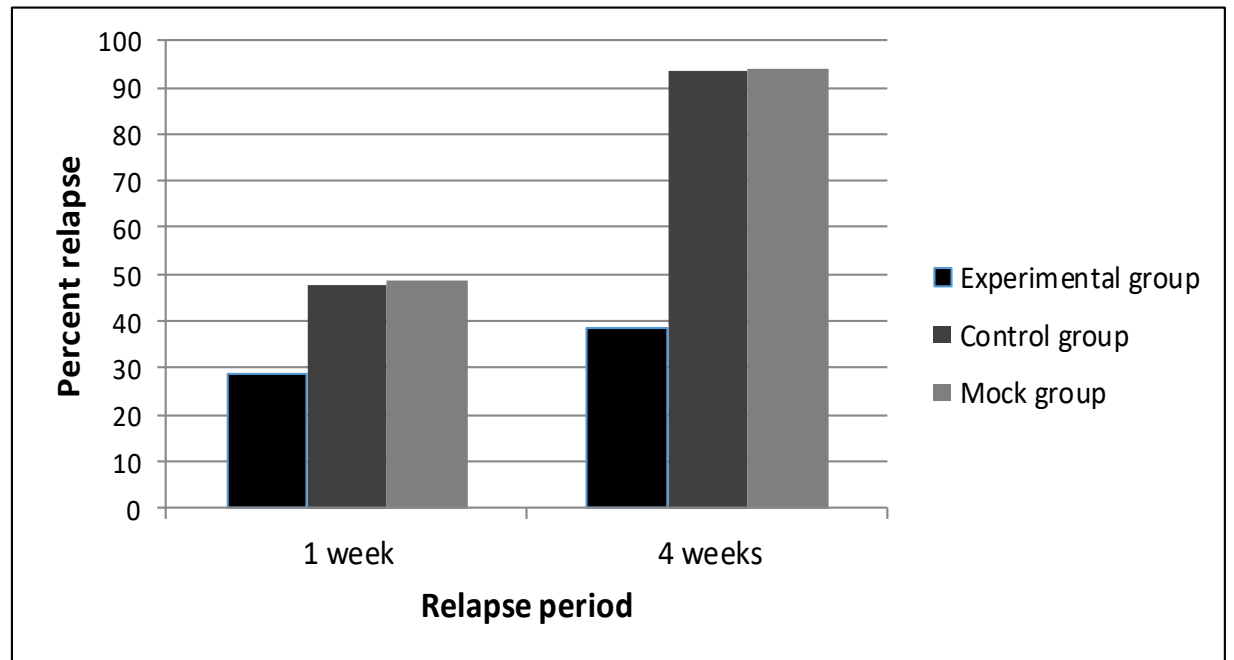

Fig. 4. A bar graph showing percent of relapse in the three study groups at different relapse periods. The percentage of relapse is distance of relapse/distance of tooth movement.

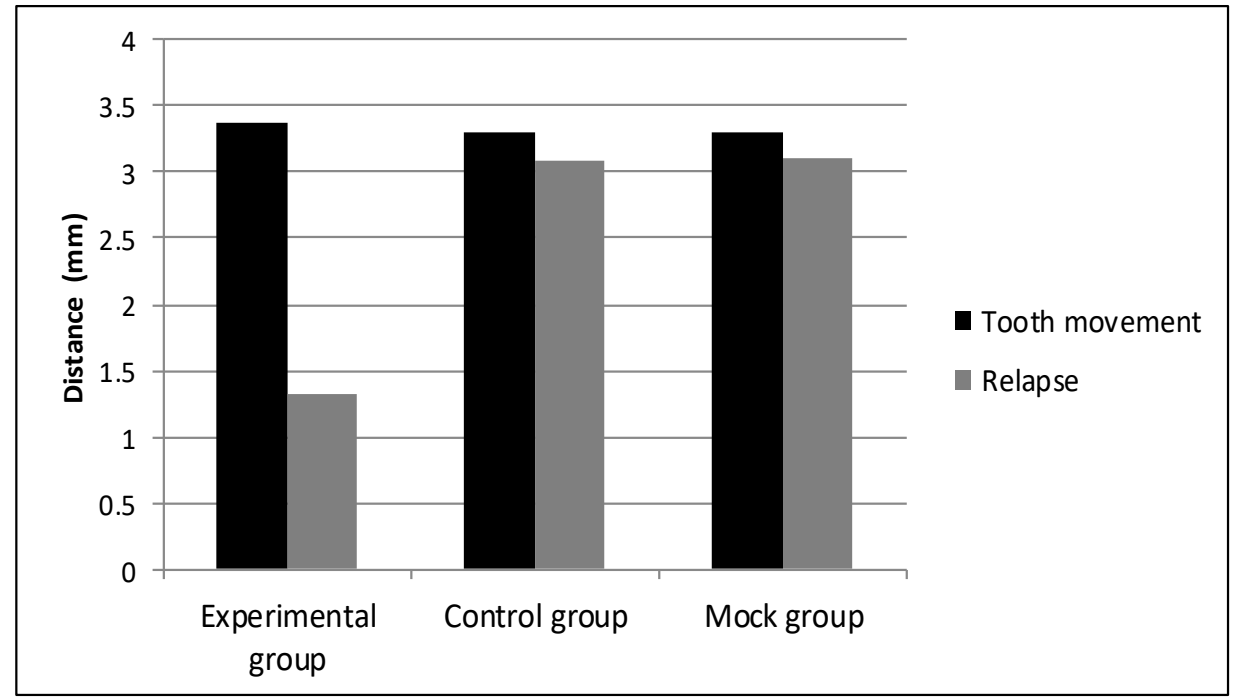

Fig. 5. A bar graph showing initial tooth movement and amount of relapse in the three study groups after 4 weeks relapse period. 
After 4 week of relapse, the distance and percentage of relapse in the experimental group $(1.32 \pm 0.46 \mathrm{~mm} ; 38.6 \% \pm 10.6 \%)$ was also significantly less than the distance and percentage of relapse in both the control group and the mock group; $(3.1 \pm 0.22 \mathrm{~mm} ; 93.73 \% \pm 1.15 \%)$ and $(3.11 \pm 0.27 \mathrm{~mm} ; 93.92 \% \pm 1.1 \%)$ respectively. No significant difference was observed between the control and the mock groups (Fig. 4 and Fig. 5).

No statistically significant difference was found between the relapse observed in the experimental groups in 1 week and 4 weeks relapse periods. However, relapse increased significantly $(\mathrm{P}<0.001)$ in both the control and the mock groups from 1 week to 4 weeks relapse period intervals (Fig. 4).

A comparison of the amounts of relapse between different study groups at different relapse intervals is shown in Table 1.

Table 1. Comparison of mean amount of relapse between different study groups at different relapse intervals

\begin{tabular}{|c|c|c|c|c|}
\hline & & $\begin{array}{c}\text { Experimental } \\
\text { Group }\end{array}$ & Control group & Mock group \\
\hline $\begin{array}{c}\text { Amount of relapse } \\
(\mathrm{mm}) \\
\text { Mean } \pm \mathrm{SD}\end{array}$ & \multirow{2}{*}{$\begin{array}{l}1 \text { week } \\
\text { relapse } \\
\text { period }\end{array}$} & $0.96 \pm 0.27^{\mathrm{a}}$ & $1.57 \pm 0.3 b$ & $1.59 \pm 0.13 b$ \\
\hline $\begin{array}{l}\text { ANOVA } \\
\text { P value }\end{array}$ & & \multicolumn{3}{|c|}{$<0.0001^{*}$} \\
\hline $\begin{array}{c}\text { Amount of relapse } \\
(\mathrm{mm}) \\
\text { Mean } \pm \mathrm{SD}\end{array}$ & \multirow{2}{*}{$\begin{array}{l}4 \text { weeks } \\
\text { relapse } \\
\text { period }\end{array}$} & $1.32 \pm 0.46 \mathrm{a}$ & $3.1 \pm 0.22 c$ & $3.11 \pm 0.27 \mathrm{c}$ \\
\hline $\begin{array}{l}\text { ANOVA } \\
\text { P value }\end{array}$ & & \multicolumn{3}{|c|}{$<0.0001^{*}$} \\
\hline $\begin{array}{c}\mathrm{t} \text { test } \\
\mathrm{P} \text { value }\end{array}$ & & $\begin{array}{l}2.11 \\
0.49\end{array}$ & $\begin{array}{c}12.817 \\
<0.0001 *\end{array}$ & $\begin{array}{c}15.731 \\
<0.0001 *\end{array}$ \\
\hline
\end{tabular}

Volume 51 - June 2017 
Egyptian

Orthodontic Journal

\section{DISCUSSION}

This randomized controlled animal study was carried out to test the hypothesis that platelet rich plasma (PRP) can be used as a safe biological retainer to minimize or prevent tooth relapse following orthodontic tooth movement. The literature reported some successful attempts for biological control of relapse using pharmacological drugs ${ }^{(9-14)}$. However, the use of PRP has superior advantages over any other pharmacological drug. PRP is an autologous blood product, hence; there is no risk of infectious disease transmission or any unexpected local or systemic adverse reactions. PRP preparation is very easy and simple, and is always executed as a chair side procedure ${ }^{(41)}$.

The spring design and the active tooth-movement period of 21 days were chosen in this study in accordance with other studies with rabbits ${ }^{(43-46)}$. Tipping movements were expected due to the spring design used over short periods of activation, ensuring that the teeth would be moved into an unstable position to increase the chance of relapse and to assess the efficiency of the proposed method of retention more clearly. The spring used in this study required no laboratory preparation and was easily applied to the rabbits' teeth. No dislocated or lost springs were observed in any of the study animals during the experiment.

An interesting finding was noted in this study that relapse showed the greatest amount in the first week after removal of the orthodontic force; the relapse in the control group and mock group after 1 week was almost half of the total distance ( $47.7 \%$ and $48.7 \%$ respectively). Then relapse continued at a slower rate with an almost complete relapse after 4 weeks in both groups. The experimental group showed the same behavior of tooth relapse, however, at a very much less amounts of first molar relapse. The experimental group showed most of the first molar relapse at the 1 week period $(28.8 \%)$ then it continued at a slower rate till the end of the 4 weeks relapse period $(38.6 \%)$. This might suggest that PRP injection speeded the remodeling of the PDL and promoted new bone formation at a higher rate helping in faster stabilization of the new tooth position. These findings comes in accordance with Hassan AH, Al-Hubail $\mathrm{A}$ and $\mathrm{Al}$-Fraidi $\mathrm{AA}^{(13)}$ who injected bone morphogenic proteins (BMPs) 
around orthodontically moved teeth and Han $\mathrm{G}$ et $\mathrm{al}^{(12)}$ after systemic administration of simvistatin following removal of orthodontic forces. Both (BMPs) and simvistatin are bone inductive materials. Their administration resulted in significant new bone formation and faster bone maturation in the treated models in comparison to the control subjects. Rapid relapse might possibly be due to a rebound in PDL compression ${ }^{(49)}$. Possibly, relapse energy stored in the collagenous periodontal and transseptal fiber systems was gradually released after spring removal $^{(50,51)}$, resulting in faster and greater relapse in the first week. As the energy dissipated, the speed and extent of relapse stepped down.

\section{CONCLUSIONS}

1. Within the limitations of the current study platelet rich plasma can be claimed a novel method of biological retention in which a biologically safe material is used to retain the teeth.

2. The periodontal injection of autologous platelet rich plasma (PRP) reduced the amount of relapse by $20 \%$ and $55 \%$ after 1 week and after 4 weeks respectively from removal of orthodontic forces when compared to the controls.

3. Relapse tends to happen immediately following removal of the orthodontic forces at the highest rate; where $48 \%$ of the achieved tooth movement relapsed after 1 week of orthodontic force removal in the control group. Therefore, immediate retention is necessary.

\section{REFERENCES}

1. Mollov ND, Lindauer SJ, Best AM, Shroff B, Tufekci E. Patient attitudes toward retention and perceptions of treatment success. Angle Orthod 2010;80(4):468-73.

2. Little RM, Riedel RA, Artun J. An evaluation of changes in mandibular anterior alignment from 10 to 20 years postretention. Am J Orthod Dentofacial Orthop 1988;93(5):423-8.

3. Little RM. Stability and relapse of dental arch alignment. Br J Orthod 1990;17(3):235-41. 
Egyptian

Orthodontic Journal

4. Sadowsky C, Sakols EI. Long-term assessment of orthodontic relapse. Am J Orthod 1982;82(6):456-63.

5. Uhde MD, Sadowsky C, BeGole EA. Long-term stability of dental relationships after orthodontic treatment. Angle Orthod 1983;53(3):240-52.

6. Ras F, Korstjens CM, Kuitert RB, van Ginkel FC, Prahl-Andersen B. The stability of orthodontic treatment over the long term. Ned Tijdschr Tandheelkd 1992;99(9):355-61.

7. Schütz-Fransson U, Bjerklin K, Kurol J. Mandibular incisor stability after bimaxillary orthodontic treatment with premolar extraction in the upper arch. J Orofac Orthop 1998;59(1):47-58.

8. Krishnan V, Davidovitch Z. Cellular, molecular, and tissue-level reactions to orthodontic force. Am J Orthod Dentofacial Orthop 2006;129(4):469.e1-32.

9. Kim T-W, Yoshida Y, Yokoya K, Sasaki T. An ultrastructural study of the effects of bisphosphonate administration on osteoclastic bone resorption during relapse of experimentally moved rat molars. Am J Orthod Dentofac Orthop 1999;115(6):645-53.

10. Kohno S, Kaku M, Kawata T, Fujita T, Tsutsui K, Ohtani J, et al. Neutralizing effects of an anti-vascular endothelial growth factor antibody on tooth movement. Angle Orthod 2005;75(5):797-804.

11. Zhao N, Lin J, Kanzaki H, Ni J, Chen Z, Liang W, et al. Local osteoprotegerin gene transfer inhibits relapse of orthodontic tooth movement. Am J Orthod Dentofacial Orthop 2012;141(1):30-40.

12. Han G, Chen Y, Hou J, Liu C, Chen C, Zhuang J, et al. Effects of simvastatin on relapse and remodeling of periodontal tissues after tooth movement in rats. Am J Orthod Dentofacial Orthop 2010;138(5):550.e1-7

13. Hassan AH, Al-Hubail A, Al-Fraidi AA. Bone inductive proteins to enhance postorthodontic stability. Angle Orthod 2010;80(6):1051-60.

14. Hirate Y, Yamaguchi M, Kasai K. Effects of relaxin on relapse and periodontal tissue remodeling after experimental tooth movement in rats. Connect Tissue Res 2012;53(3):207-19. 
Egyptian

Orthodontic Journal

15. Foster TE, Puskas BL, Mandelbaum BR, Gerhardt MB, Rodeo SA. Platelet-rich plasma: from basic science to clinical applications. Am J Sports Med 2009;37(11):2259-72.

16. Aspenberg $\mathrm{P}$, Virchenko O. Platelet concentrate injection improves Achilles tendon repair in rats. Acta Orthop Scand 2004;75(1):93-9.

17. De Mos M, van der Windt AE, Jahr H, van Schie HTM, Weinans H, Verhaar JAN, et al. Can platelet-rich plasma enhance tendon repair? A cell culture study. Am J Sports Med 2008;36(6):1171-8.

18. Kondo E, Yasuda K, Yamanaka M, Minami A, Tohyama H. Effects of administration of exogenous growth factors on biomechanical properties of the elongation-type anterior cruciate ligament injury with partial laceration. Am J Sports Med 2005;33(2):188-96.

19. Randelli PS, Arrigoni P, Cabitza P, Volpi P, Maffulli N. Autologous platelet rich plasma for arthroscopic rotator cuff repair. A pilot study. Disabil Rehabil [Internet]. 2008 Jan [cited 2015 Aug 29]; 30(20-22):1584-9.

20. Sánchez M, Anitua E, Azofra J, Andía I, Padilla S, Mujika I. Comparison of surgically repaired Achilles tendon tears using platelet-rich fibrin matrices. Am J Sports Med. 2007;35(2):245-51.

21. Schnabel L V, Mohammed HO, Miller BJ, McDermott WG, Jacobson MS, Santangelo KS, et al. Platelet rich plasma (PRP) enhances anabolic gene expression patterns in flexor digitorum superficialis tendons. J Orthop Res 2007;25(2):230-40.

22. Anitua E, Andia I, Ardanza B, Nurden P, Nurden AT. Autologous platelets as a source of proteins for healing and tissue regeneration. Thromb Haemost 2004;91(1):4-15.

23. El-Sharkawy H, Kantarci A, Deady J, Hasturk H, Liu H, Alshahat M, et al. Platelet-rich plasma: growth factors and pro- and anti-inflammatory properties. J Periodontol 2007;78(4):661-9.

24. Babbush CA, Kevy S V, Jacobson MS. An in vitro and in vivo evaluation of autologous platelet concentrate in oral reconstruction. Implant Dent 2003;12(1):24-34. 
Egyptian

Orthodontic Journal

25. Eppley BL, Woodell JE, Higgins J. Platelet quantification and growth factor analysis from platelet-rich plasma: implications for wound healing. Plast Reconstr Surg 2004;114(6):1502-8.

26. Fréchette J-P, Martineau I, Gagnon G. Platelet-rich plasmas: growth factor content and roles in wound healing. J Dent Res 2005; 84(5):434-9.

27. Grotendorst GR, Martin GR, Pencev D, Sodek J, Harvey AK. Stimulation of granulation tissue formation by platelet-derived growth factor in normal and diabetic rats. J Clin Invest 1985;76(6):2323-9.

28. Tanaka H. Effect of IGF-I and PDGF administered in vivo on the expression of osteoblast-related genes in old rats. $\mathrm{J}$ Endocrinol 2002;174(1):63-70.

29. Lieberman JR, Daluiski A, Einhorn TA. The role of growth factors in the repair of bone. Biology and clinical applications. J Bone Joint Surg Am 2002;84-A(6):1032-44.

30. Tischler M. Platelet rich plasma. The use of autologous growth factors to enhance bone and soft tissue grafts. N Y State Dent J 2002;68(3):22-4.

31. Street J, Bao M, deGuzman L, Bunting S, Peale F V, Ferrara N, et al. Vascular endothelial growth factor stimulates bone repair by promoting angiogenesis and bone turnover. Proc Natl Acad Sci 2002;99(15):9656-61.

32. Mayr-Wohlfart U, Waltenberger J, Hausser H, Kessler S, Günther K-P, Dehio C, et al. Vascular endothelial growth factor stimulates chemotactic migration of primary human osteoblasts. Bone 2002;30(3):472-7.

33. Urist MR, Mikulski AJ, Nakagawa M, Yen K. A bone matrix calcification-initiator noncollagenous protein. Am $J$ Physiol 1977;232(3):C115-27.

34. Herrera BS, Coimbra LS, Bastos AS, Teixeira SA, Steffens JP, Muscara $\mathrm{MN}$, et al. Platelet-rich plasma stimulates cytokine expression and alkaline phosphatase activity in osteoblast-derived osteosarcoma cells. Arch Oral Biol 2012;57(9):1282-9. 
Egyptian

Orthodontic Journal

35. Zhong W, Sumita Y, Ohba S, Kawasaki T, Nagai K, Ma G, et al. In vivo comparison of the bone regeneration capability of human bone marrow concentrates vs. platelet-rich plasma. PLoS One 2012; 7(7):e40833.

36. $\mathrm{Xu} \mathrm{H}$, Ke K, Zhang Z, Luo X, Jin X, Liu SS-Y, et al. Effects of platelet-rich plasma and recombinant human bone morphogenetic protein-2 on suture distraction osteogenesis. J Craniofac Surg 2013;24(2):645-50.

37. Kassolis JD, Reynolds MA. Evaluation of the adjunctive benefits of platelet-rich plasma in subantral sinus augmentation. J Craniofac Surg 2005;16(2):280-7.

38. Arora NS, Ramanayake T, Ren YF, Romanos GE. Platelet-rich plasma: a literature review. Implant dentistry 2009;18(4):303-10.

39. Application of platelet-rich plasma in maxillofacial surgery: clinical evaluation.

40. Anila S, Nandakumar K. Applications of platelet rich plasma for regenerative therapy in periodontics. J Trends Biomater Artif 2006; 12:452-476.

41. Marx RE, Carlson ER, Eichstaedt RM, Schimmele SR, Strauss JE, Georgeff KR. Platelet-rich plasma: Growth factor enhancement for bone grafts. Oral Surg Oral Med Oral Pathol Oral Radiol Endod 1998;85(6):638-46.

42. Roche JJ, Cisneros GJ, Acs G. The effect of acetaminophen on tooth movement in rabbits. Angle Orthodontist. 1997;27:231-6.

43. Roche JJ, Cisneros GJ, Acs G. The effect of acetaminophen on tooth movement in rabbits. Angle Orthod 1997;67(3):231-6.

44. Pithon MM, Ruellas AC de O. Avaliação histológica da influência do fenobarbital (Gardenal ${ }^{\circledR}$ ) na movimentação ortodôntica: estudo em coelhos. Dental Press J Orthod 2011;16(4):47-54.

45. Journals I, Venkataramana V1 RKKNCMA. The Effect of Bisphosphonate [Pamidronate] On Orthodontic Tooth Movement in Rabbits. 2014;3:301-312 
46. Yu J-Y, Lee W, Park JH, Bayome M, Kim Y, Kook Y-A. Histologic effects of intentional-socket-assisted orthodontic movement in rabbits. Korean J Orthod 2012;42(4):207-17.

47. Nagata MJH, Messora MR, Furlaneto FAC, Fucini SE, Bosco AF, Garcia VG, et al. Effectiveness of two methods for preparation of autologous platelet-rich plasma: an experimental study in rabbits. Eur J Dent 2010;4(4):395-402.

48. Luengo Gimeno F, Gatto S, Ferro J, Croxatto JO, Gallo JE. Preparation of platelet-rich plasma as a tissue adhesive for experimental transplantation in rabbits. Thromb J 2006;4:18-27.

49. Reitan K, Ballard CF, Björk A, Burstone CJ, Groves MH, Graber TM, et al. Clinical and histologic observations on tooth movement during and after orthodontic treatment. Am J Orthod Dentofac Orthop 1955;53(10):721-45.

50. Sadowsky C, Schneider BJ, BeGole EA, Tahir E. Long-term stability after orthodontic treatment: nonextraction with prolonged retention. Am J Orthod Dentofacial Orthop 1994;106(3):243-9t

51. Parker GR. Transseptal fibers and relapse following bodily retraction of teeth: A histologic study. Am J Orthod 1972;61(4):331-44. 